\title{
The changing nature of city tourism and its possible implications for the future of cities
}

\author{
Kerstin Bock ${ }^{1}$ \\ Received: 31 October 2015 / Accepted: 25 November 2015 /Published online: 12 December 2015 \\ (C) The Author(s) 2015. This article is published with open access at Springerlink.com
}

\begin{abstract}
City tourism is one of the fastest growing travel segments worldwide [18] and the changing nature of city tourism becomes increasingly apparent in many cities. Facilitated by mobile access to information, tourists are increasingly seeking, finding and consuming 'local experiences' and the boundaries between tourists and residents become increasingly blurred. While the impact of the proliferation of information and communication technologies (ICTs) on the travel industry as well as on tourist behaviour and the travel experience has been widely acknowledged (Egger J Hosp Tour Technol 4(2): 119-133, 2013), (McCabe et al. Tour Manage Perspect 4: 36-44, 2012), (Stamboulis and Skayannis Tour Manage 24 : 35-43, 2003), [35, 40], (Ye et al. Comput Hum Behav 27: 634-639, 2011), the implications of this new type of tourism for future urban development have received little attention (Füller and Michel Int J Urban Regional 38(4): 1304-1318, 2014). This paper aims to better understand the underlying causes of the changing nature of city tourism and how this change could impact the future development of cities. It is argued that in addition to the proliferation of ICTs, the phenomena of experiential travel and social acceleration have contributed to the rise in popularity of city tourism as well as to a change in tourist behaviour. Possible implications for the future development of cities resulting from this new type of tourism, as well as approaches to solving those challenges, are discussed. It becomes clear that an interdisciplinary approach will be required in order to fully understand the challenges posed by city tourism as well as to develop and
\end{abstract}

Kerstin Bock

kerstin@zedat.fu-berlin.de

1 Department of Futures Research, Faculty of Education and Psychology, Freie Universität Berlin, Berlin, Germany implement strategies for a successful integration of tourism into future urban development.

Keywords City tourism - Tourist behaviour - Experiential travel $\cdot$ Social acceleration $\cdot$ Information and communication technologies (ICTs) · Urban development

\section{Introduction}

Although cities and their development have without doubt been increasingly shaped by tourism in the past decades, discussions of the links between city tourism and its impact on a city's development remain scarce. City tourism is one of the fastest growing travel segments worldwide [18] and the impacts of the changing nature of city tourism become increasingly apparent in many cities. The proliferation of information and communication technologies (ICTs) has had a significant impact on the travel industry, as well as on tourist behaviour, and is also transforming the nature of travel and the actual tourist experience [9, 22].

While the general impact of ICTs on the travel industry and tourist behaviour has been widely acknowledged [9, 19, 30, $35,40,41]$, an understanding of the impact of ICTs on the nature of city tourism, and consequently on urban transformation and the future development of cities, has received little attention [13]. As travel experiences become increasingly dominated by ICTs, a change in travel behaviour can be observed in cities around the world. Therefore, the aim of this paper is to examine the changing nature of city tourism, as well as the underlying causes of this change, by means of a literature review. Moreover, possible consequences of this phenomenon for the future development of cities will be delineated.

The first part of this paper provides a brief overview of the growth of city tourism and discusses possible reasons for the 
popularity of this type of tourism. Then, the changing nature of city tourism will be explored by focusing on the effects of the proliferation of ICTs on travel behaviour as well as on the phenomena of experiential travel and social acceleration. Based on these considerations, some of the challenges that city tourism and the changing tourist behaviour pose to the future of cities, and possible implications, will be discussed. This is followed by an outlook for the future of city tourism as well as by exploring possible approaches to solving challenges resulting from this new type of tourism.

\section{City tourism}

\section{The rise of city tourism}

More than half of the world's population lives in cities today and by 2030 an estimated five billion people will live in urban areas. As vibrant epicentres of culture and commerce, some of the world's greatest tourism destinations are cities, attracting a growing number of visitors every year [37]. According to the United Nations World Tourism Organization (UNWTO), city tourism - also referred to as urban tourism - is considered as "trips taken by travellers to cities or places of high population density. The duration of these trips is usually short (one to 3 days)..." [UNWTO, 2012, cited in: $36: 8][36]$.

While total international tourist arrivals are increasing year on year, different trends regarding different segments and types of trips can be observed. According to Euromonitor International [12], international tourist arrivals have increased by $4.8 \%$ in 2013, while the world's 100 leading cities in terms of international tourist arrivals have experienced a growth of $5.4 \%$ in the same year. Although these growth figures include different trip purposes, including business trips, a rise in city tourism can also be observed when looking at holiday segments. While sun \& beach holidays have grown by $31 \%$ over the last 5 year period (representing $29 \%$ of all holiday trips), the segment of touring holidays has grown by $28 \%$ (to reach a $23 \%$ share). The city trips segment, however, has increased by $72 \%$ during the past 5 years to reach a share of $21 \%$ [18]. In some countries, city trips have already overtaken sun $\&$ beach holidays as the most popular type of holidays. For example, $42 \%$ of British people took a city break holiday in 2014, compared to $38 \%$ who went on a sun $\&$ beach holiday in the same year [1].

In order to understand the implications for the future of cities, it is important to also look at the development of city trips from a city's perspective. Using Barcelona and Berlin as examples, the enormous growth some cities have experienced in terms of tourist arrivals since 1990 can be illustrated. Arrivals in hotels and similar accommodation establishments in the city area of Barcelona have grown from 1.7 million in 1990 to 7.5 million in 2013. In the city area of Berlin, arrivals in all paid forms of accommodation establishments have increased from 2.8 million in 1990 to 11.3 million in 2013 [32]. What implications this growth already has on cities today, and what they might be in the future, will be discussed in more detail later. In the following section, some of the reasons for the popularity of city tourism will be explored.

\section{The popularity of city tourism}

What makes city tourism distinct from other types of tourism is that cities have a high density of diverse cultural offerings in a relatively small area, attracting different types of tourists. Moreover, most attractions and amenities tourists are drawn to have not been primarily intended for tourists, which often leads to an interaction between tourists and locals. As these characteristics of city tourism are not new, the question that arises is why the popularity of city tourism has drastically increased in recent years.

A number of factors may have contributed to the rising popularity of city tourism. Firstly, urbanisation is believed to reinforce the trend towards city tourism as people living in cities are more likely to associate with cities and the more they are inclined to visit other cities [37]. Secondly, without doubt the proliferation of low cost carriers has had a major impact on the popularity of city trips, mainly due to the fact that they made flights more affordable to the masses, but also because they expanded and improved flight networks, thus offering more city destination options and making them more accessible from a growing number of departure points than in the past, considerably decreasing travel times. As a consequence, this development has made a wide range of cities available to tourists at lower costs [8]. Thirdly, as the proportion of the population taking several trips per year continues to grow, there is a tendency towards an increasing number of shorter holidays rather than just one main holiday per year [8, 17, 34]. Fourthly, due to the increasing availability and penetration of internet based services during the travel cycle, information can easily be accessed, and the ease of making bookings online, and retrieve a wide range of information while in a destination, has greatly facilitated city tourism. As the biggest proportion in terms of the booking value of a city trip usually consists of the two elements transport and accommodation, it is relatively easy and not as risky to book online as, for example, a multi-country trip, a round trip or even a beach holiday where the hotel is not easily accessible from the airport by public transport. Moreover, as will be discussed in more detail later, the proliferation of ICTs, and in particular of mobile technologies, increasingly empowers consumers to create and plan further components of their city trip while in the destination. Due to the density of cultural offerings, the amount of options to choose from in a city surpasses those of other destination types. Finally, peoples' perceptions of cities as tourist destinations has been changing. Nowadays, travellers no longer regard a city merely as an entry, exit, or transit point, but as a destination in its own right [8]. 


\section{The changing nature of city tourism}

\section{The proliferation of ICTs}

In our increasingly mobile and connected world, devices connected to the internet, and increasingly mobile devices, such as smartphones and tablets, are omnipresent. In terms of both product sales and broadband subscriptions, mobile devices are now outperforming PCs [28]. According to Ericsson [10], approximately $90 \%$ of the world's population will be covered by mobile broadband networks by 2020 . Global mobile subscriptions are growing by around $5 \%$ year on year. By 2020 , smartphone subscriptions are forecast to have more than doubled and $70 \%$ of the world's population will own a smartphone [10]. As a result, mobile devices are set to play an increasingly important role in travel in the years to come [28].

In the past, ICTs have not only revolutionised the travel industry itself but also the role of consumers, who have acquired greater power thanks to the array of information available and the choices offered by the internet. However, the inexorable rise of the mobile channel and smartphones has triggered a new stage in this development, which is not only expected to have a major impact on the travel industry but also a significant impact on the travel behaviour. While in the past travellers used ICTs for pre-travel and post-travel arrangements, there has been a general shift to using mobile technologies during the travel experience as many travellers are nowadays connected to the internet during all stages of the travel cycle [11, 20, 42].

Smartphone applications provide a wide range of information, such as destination tour guides, language assistants, restaurant and bar finders, information on local transportation, events, etc. Moreover, users interact with each other via social media and provide reviews on places, local attractions, restaurants and bars as well as on accommodation, which in turn are read by tourists deciding on their own travel plans and things to do while in the destination. This results in the mobile internet changing tourists' behaviour as they are now able to find what they require and when they require it through their mobile devices [6, 19, 23]. More easily available information increases the number and types of experience options a tourist can choose from in a shorter period of time.

While it has to be acknowledged that access to free Wi-Fi is still limited in some destinations, there is a rapid development towards mobile contract providers offering cheaper internet allowances for travellers on the one hand and cheaper or free internet access in hotels, cafes, and even throughout some cities on the other. At the same time, more elaborated apps are being developed for offline use. For example, Google is planning to offer new offline features that will allow navigating around a city in offline mode. Moreover, through Google's new context-aware service, Now on Tap, tourists will be able to build a temporary offline library with all relevant data and information they would need for a day, for example of where they want to travel and what they are planning to visit. The data download can be completed while the mobile device is connected to free Wi-Fi, for example at the airport, accommodation and other Wi-Fi zones and hotspots and thus, expensive internet fees can be avoided [24]. According to Tripadvisor [34], $74 \%$ of global travellers surveyed regarded free in-room Wi-Fi as the most influential amenity when booking accommodation. Furthermore, $87 \%$ of global travellers use mobile devices while travelling, with $61 \%$ of global travellers using social media while on holidays [33]. With a rapid expansion of the availability of free or cheap Wi-Fi access, the use of mobile internet devices by travellers is set to further increase in the future.

\section{Experiential travel \& social acceleration}

Nowadays, travellers are increasingly in search for rich and memorable experiences that create value for them and engage them in a personal way. There are two major developments which can currently be observed with regard to the travel experience. The first one is the traditional experience economy being increasingly replaced by the concept of experience co-creation, meaning that consumers are becoming more active in co-creating their experiences. The second one, a more recent development, is that experiences become increasingly dominated by ICTs. As a result of travellers becoming more empowered through the use of technologies during their travels, they themselves can now become the main actor in co-creating richer experiences and additional value [21, 29].

Travel is increasingly about how travellers experience destinations viscerally and how experiences change them and their understanding of places. They want to feel inspired by places and their encounters with locals - and they want individual experiences that are entirely their own. This phenomenon is commonly referred to as 'Experiential Travel' and is arguably the most significant, systemic trend in global travel. The term typically encompasses the notion of a more immersive, authentic and local and/or active travel experience. While it could be argued that travel is inherently experiential, the significance in this context is the shift towards the mainstream. An increasing number of people want to travel on a deeper emotional and more personal level and are turning their backs on pre-arranged package holidays [21, 29].

One reason for the development of this trend might be the sameness of many mainstream travel experiences. Another reason, according to Wong, the founder and CEO of Vayable, an online sharing portal that pairs travellers with its network of local citizens around the globe offering to experience their destination like a local, is the fact that technology, while connecting individuals online, has ironically left people isolated and given individuals a real need for human connection 
[29]. While these are plausible reasons for this change in tourist behaviour, it is suggested here that another explanation might lie in the acceleration of society as described by the sociologist Hartmut Rosa [25-27]. In fact, social acceleration may not only explain the shift towards experiential travel and the increased use of internet devices while travelling, but might also offer an explanation for the enormous popularity of city tourism.

Rosa differentiates between three categories of acceleration: technological acceleration, the acceleration of social change, and the acceleration of the pace of life. Technological acceleration is "the speeding up of intentional, goal-directed processes of transport, communication, and production" [26:6]. While technological acceleration could be classified as acceleration processes within society, acceleration of social change can be described as acceleration of society itself. The acceleration of social change is what Rosa describes as the "contraction of the present (Gegenwartsschrumpfung)" [26:7], the present being the time-span for which "the horizons of experience and expectation coincide" [26:7]. Social beliefs and actions have an increasingly shorter period of validity; social change is for example reflected in the stability of social institutions and practices as well as in personal relationships. Finally, the acceleration of the pace of life, which occurs despite the expectation that technological progress increases an individual's free time, can be defined as the "increase of episodes of action and/or experiences per unit of time as a result of a scarcity of time resources" [27:221].

These three categories of acceleration can be understood as an acceleration cycle: Technological acceleration is almost inevitably linked to a whole range of changes in social practices and communication structures. For example, the internet has not only speeded-up communication processes but also triggered new economic and communicative structures, establishing new patterns of social interaction and thus, driving social change. In a society where accelerated rates of social change affect all spheres of life, individuals develop a feeling of standing on a 'slippery slope', a phenomenon that is well known from the realm of capitalist production. Pausing and resting means becoming out-dated and old-fashioned in one's knowledge and experience. Therefore, in order to avoid the loss of potentially valuable options, individuals feel forced to keep up with the speed of change they experience in their social and technological environment. This social change again leads to an acceleration of the pace of life, which in turn calls for technological acceleration to speed up processes in a repeated attempt to save time [26].

This acceleration circle that can be observed in Western societies is inextricably linked with the culturally dominant idea of the 'good life', according to which life should be conceived as the last opportunity, and one's time span on earth should be used as intensively and comprehensively as possible. According to this modern ideal, the 'good life' is the full life (erfülltes Leben), and one should aspire to enjoy as much as possible of what the world has to offer by realising as many options as possibly realisable - or as Rosa states:

"[t]he idea of the fulfilled life no longer supposes a 'higher life' waiting for us after death, but rather consists in realizing as many options as possible from the vast possibilities the world has to offer. To taste life in all its heights and depths and in its full complexity becomes a central aspiration of modern man" [26:13, italics in original].

The acceleration of life can be seen as an attempt to realise as many options as possible in our lifetime. Yet, due to the acceleration cycle's self-propelling dynamic, this aim can never be fulfilled. For example, the internet not only speeds up communication and information processes, but it also vastly increases our options. We could possibly find more relevant, better or more interesting information if we kept on looking on other websites that might better serve our purpose than merely on the one website we visited in the first place. Consequently, the proportion of realised world options to potentially realisable options decreases; technological acceleration leads to increasing time scarcity [26]. Moreover, Rosa suggests that as the number of experiences in a given period of time increases, the depth of individual experiences might decrease, which in turn might lead to individuals looking for more 'extreme' experiences [25].

Looking at city tourism through the lens of social acceleration, this type of holiday is arguably the most suitable holiday type when pursuing the 'good life' due to the high density and vast number of possible realisable options a city has to offer. ICTs, and especially mobile devices, serve as technological accelerators, through which an increasing number of options can be realised, albeit increasing the rate of potential options at greater speed and thus, decreasing the proportion of realised 'city options' to potentially realisable options a city has to offer. As the number of experience episodes increases and the depth of those individual experience episodes decreases, as suggested by Rosa, travellers might look for a different quality of their experiences. The phenomenon of experiential travel might be the manifestation of this search for a different quality of experiences, for a quest for more 'extreme' experiences - from one extreme of being a tourist to another extreme of living like a local for a short period of time.

Therefore, it could be suggested that social acceleration could be regarded as both cause and effect of the changing nature of city tourism; a cause because the progress and proliferation of technology might enhance the need for human connection and meaningful experiences while increasing the potential options of experience episodes; and an effect because as a result of these phenomena, the attractiveness of cities as destinations increases due to the multitude of options 
paired with the opportunity of immersing oneself in meaningful and local experiences for a short period of time. While ICTs could be regarded as facilitators of this change, social acceleration may be a useful framework to understand and analyse the underlying causes as well as the qualitative shift of tourist behaviour, and may even be useful to anticipate tourists' future needs and behaviours.

\section{Possible implications for the future of cities}

\section{Challenges and possible implications of city tourism}

The boundaries between tourists and locals become increasingly blurred. This is because on the one hand the borders between tourists and residents become more difficult to define due to globalisation and changing developments related to the way people work and live. These changes result for example in a rise of long working holidays, medium-term business travel, commuting between two countries, and similar phenomena [14]. On the other hand the blurring of boundaries occurs because tourists are increasingly blending in with the local population. While in the past tourists mainly frequented tourist hot spots and officially designated tourist attractions, they are increasingly seeking 'authentic and local experiences', exploring ordinary but lively and diverse neighbourhoods and visiting cafes, bars and markets that were previously almost exclusively frequented by locals. This results in an interest in the same amenities, entertainment and retail infrastructure that city residents preferably consume. However, as leisure tourists are often not constrained on sleeping hours or spending power to the same extent as local residents, conflicts between tourists and residents increasingly occur in neighbourhoods that, in the past, have not been on the (analogue) tourist map. Causes of conflicts are for example nightly partying tourist crowds in residential areas as well as the transformation of affordable local pubs, grocery stores and markets into hyped, high-priced locations that become unaffordable to many local residents [13]. Moreover, this kind of development can slowly lead to residential areas losing their unique identity and character due to businesses increasingly adapting their offerings to the lucrative tourist demand, but can also pose development opportunities for deprived areas.

Due to the proliferation of ICTs, the information divide between tourists and locals is slowly dissolving. While in the past residents almost exclusively shared and exchanged information about new restaurants, unique shops, grocery stores and markets as well as about meet-ups and other events through word-of-mouth (offline) with friends, family and other residents, and tourists did not have access to this kind of information, nowadays there is almost a complete information transparency, no longer making any difference between tourist and local resident.
The quest for the authentic is not solely limited to tourist activities but also increasingly affects accommodation choices. Companies providing online platforms that permit the large-scale rental of apartments, rooms and entire properties from one individual to another have become hugely successful in recent years. Often referred to as sharing economy or collaborative consumption, in more general terms this concept involves individuals temporarily renting, or getting access to, goods or services offered by other individuals (peerto-peer sharing). This new way of sharing and reaching a global audience has been facilitated by the Web 2.0 technology $[3,15]$. Arguably one of the most prominent - and most successful - companies of the sharing economy is Airbnb. As of August 2015, Airbnb had more than 1.5 million listings in more than 190 countries, and more than 40 million guests had booked their stay through the booking platform [2], which highlights the business concept's huge popularity amongst travellers, and even amongst an increasing number of business travellers. It is estimated that Airbnb already accounts for a similar number of room nights as some major hotel brands [15]. According to Airbnb's CEO, the company's goal is to deliver local experiences to its customers, accessible through the internet, and increasingly through mobile devices. In early 2012, Airbnb announced its acquisition of NabeWise, and a few months later the acquisition of Localmind. While NabeWise offers travellers staying with Airbnb information about nearby businesses, Localmind provides information on what is happening in local neighbourhoods. In the same year, Airbnb introduced a new 'Neighbourhoods' feature on its website, which is essentially a travel guide that includes advice from hosts and other Airbnb users, helping users of the website and app to decide where to stay and what to visit in order to experience a city 'like a local' [16, 31].

The company's enormous success not only highlights changing tourist preferences, but has also implications for cities, their residents and businesses. Not only will traditional accommodation establishments and other businesses be affected by an increasing competition from the sharing economy, but the sharing economy is also increasingly causing fears of gentrification, and particularly of rising rents and property prices, amongst local residents. While there is little evidence to what degree the sharing economy, and tourism in general, is accelerating gentrification processes, in some cities tourists have been blamed for waves of gentrification processes by local residents. In recent years, this resentment towards tourists has become particularly evident in the cities of Barcelona and Berlin. Many of the problems and challenges faced by both cities and their residents are summarised in the documentaries Bye Bye Barcelona [4] and Welcome Goodbye [39]. From these documentaries it also becomes evident that often a negatively biased view of tourism exists among city residents. What also becomes clear from having watched these documentaries as well as from having reviewed the literature 
and having attended presentations and seminars about the topic is that there is a lack of solutions from politicians, tourism businesses and city planners to these challenges.

\section{Outlook}

According to UNWTO projections, international tourist arrivals worldwide are expected to rise from 1.1 billion in 2014 to 1.4 billion by 2020 and to 1.8 billion by the year 2030 [38]. By 2030, an estimated five billion people will live in urban areas [37]. Given these two projections and the notion that people who live in cities are more likely to take city trips than people who live outside urban areas, it is very likely that city tourism is going to experience a sharp growth in the future, adding millions of tourists to a growing urban population. Due to the changing nature of city tourism, these tourists are increasingly looking for the same or similar experiences and amenities as local residents and are using to a large extent the same resources as cities' inhabitants. Therefore, when developing future city plans or city visions, it is important to acknowledge the importance of tourism and to integrate tourism into those plans.

There are going to be enormous challenges to be solved, and if these are not going to be taken seriously by politicians and city planners, a deterioration of the quality of life in many cities might be the inevitable consequence. Already today, the balance between tourists' and locals' needs in certain cities - or parts of cities - is not given anymore. For example, in Venice and Barcelona, many parts of the city have undergone a process that could be described as 'museumisation'. Those parts of the city are being enjoyed and consumed by tourists but can usually not be enjoyed by locals any longer. Due to the changing nature of city tourism as previously discussed, this process of museumisation could be amplified to affect more city locations, that have not been designated or apparent tourist areas in the past, in a shorter period of time than ever before.

As technological developments have facilitated a change in tourist behaviour, technology could also be part of the solution to some challenges city tourism poses to the future of cities. For example, the concept of smart cities - also sometimes referred to as urban informatics - uses ICTs to improve the understanding of peoples' needs. While the primary goal of smart city projects is to better manage resources and improve residents' quality of life, smart cities could better manage tourist flows in the future than cities that are not making use of big data in order to plan and manage tourism. This could offer new opportunities to governments and city planners and online data could be used as a digital reflection of physical spaces. For example, the use of GPS information could assist in determining which areas of a city are visited primarily by tourists or locals. Furthermore, city and tourism planners could analyse which places are the most popular - or becoming increasingly popular - by looking at the places' geotagged information and photos and thus, develop a better understanding of what people appreciate about certain places. This information could also be used to understand and influence behavioural patterns and tourist flows in a city and to spread tourist flows to certain parts of a city $[5,42]$. In order for these strategies to be successful, it is of paramount importance to involve the local population and businesses, develop an understanding of the importance of keeping tourist streams in balance to avoid a negative impact on the quality of life of residents, and to clearly communicate the benefits that tourism contributes to cities and their residents; not only from a general economic point of view and its export value but also by indirectly supporting the quality of life of locals, for example through the creation of a more diverse cultural offer, improved public transport, regeneration projects, etc. It would go beyond the scope of this paper to explore these options in more detail but it is worth noting that one of the cities introducing new technologies to investigate how to make tourist flows more predictable and manageable is Amsterdam. The city is working on a project aimed at spreading tourist streams to areas that have not typically been visited by tourists in the past by involving the local population, businesses and authorities. It will be interesting to follow this development and to see if Amsterdam could be a model for tourist cities in the future - and other cities should follow soon as long-term planning is of vital importance. For example, with projects like the deviation of visitor streams it might take between 8 and 12 years until changes become visible [7]. Given the importance of solving the challenges discussed in this paper, research into urban development should try to better understand new developments in tourism in order to be able to plan for cities of the future.

\section{Conclusion}

The aim of this paper was to examine the changing nature of travel behaviour in cities, as well as causes of this change, and to delineate possible consequences of this phenomenon for the future development of cities. For this purpose, possible causes of a change in tourist behaviour have been explored, mainly by examining the proliferation of ICTs as well as the phenomenon of experiential travel. Moreover, it was discussed if social acceleration could offer an additional explanation for the underlying causes of the rising popularity and changing nature of city tourism. While ICTs could be considered as facilitators of a change in tourist behaviour, the phenomenon of social acceleration may be a useful framework to understand the underlying causes as well as the qualitative shift of tourist behaviour, and may even be useful to anticipate future tourist behaviour.

It became clear that due to a change in tourist behaviour, the boundaries between tourists and residents become more and more blurred. Facilitated by mobile access to information while travelling, tourists are increasingly seeking, and finding, more authentic experiences and are looking for ways to experience cities like locals do; they increasingly want to live like a 
local for the duration of their trip. This has several implications for cities and is going to become even more important as the segment of city tourism is set to significantly increase in the future. While in the academic literature little attention has been paid to the challenges that many cities will have to face in the future, some city and tourism authorities have started to recognise these, and to develop solutions.

Due to the limited scope of this paper, various aspects related to this field of research could not be fully examined and pose a limitation to discussing this topic to a greater extent. The following examples are merely a fraction of topics that should be addressed in the future in order to gain a better understanding of the subject.

Firstly, it would be important to gain a better understanding of views and attitudes of local residents towards tourists and of how those views are changing over time in different cities. More research is also required into how residents can successfully be involved in tourism planning projects and how an awareness of tourism's benefits can positively influence locals' attitudes. Secondly, a better understanding of the extent to which tourism contributes to the process of gentrification is required but also an understanding of how tourism can be used to develop deprived areas and enhance the quality of life for residents. Thirdly, a detailed understanding of why tourists are drawn to certain areas and locations and not to others, how meanings of places are being created and are changing over time, and of the role of technology during these processes would be important for future research. Fourthly, differences in tourist behaviour, for example by global region, age, income, etc. should be looked at in greater detail. If links between behavioural patterns and other variables could be established, this might help to better anticipate tourist behaviour in the future. Fifthly, it is of vital importance to establish viable future options for destinations with confined space, such as Venice or Vatican City. Moreover, a comprehensive analysis of best practice examples of city tourism strategies around the globe as well as a detailed review of existing and emerging technologies that could play an important role with regard to city tourism could help cities to better plan and prepare for the future. In order to fully understand the future challenges of city tourism as well as possible implications for the future of cities, and to successfully develop and implement strategies, an interdisciplinary approach will be required.

Open Access This article is distributed under the terms of the Creative Commons Attribution 4.0 International License (http:// creativecommons.org/licenses/by/4.0/), which permits unrestricted use, distribution, and reproduction in any medium, provided you give appropriate credit to the original author(s) and the source, provide a link to the Creative Commons license, and indicate if changes were made.

\section{References}

1. ABTA (2014) The consumer holiday trends report - ABTA consumer survey 2014 [pdf] London: ABTA Ltd. Available at: https:// c0e31a7ad92e875f8eaa-5facf23e658215b1771a91c2df41e9fe.ss1. cf3.rackcdn.com/publications/1420_ABTA_Consumer_Survey 2014_WEB.pdf. Accessed: 4 Aug 2015

2. Airbnb (2015) About Us. [Online] Available at: https://www. airbnb.co.uk/about/about-us. Accessed 21 Aug 15

3. Belk R (2014) You are what you can access: Sharing and collaborative consumption online. J Bus Res, 1595-1600

4. Bye Bye Barcelona (2014) Directed by Eduardo Chibás Fernández [Film]. Spain

5. Cisco (2014) Smart city infrastructure is helping Europe's cities better understand and serve tourists. [ONLINE] Available at: http://newsroom.cisco.com/press-release-content?type= webcontent\&articleId=1488545. Accessed 07 Aug 15

6. Dickinson JE, Ghali K, Cherrett T, Speed C, Davies N, Norgate S (2014) Tourism and the smartphone app: capabilities, emerging practice and scope in the travel domain. Curr Issues Tour 17(1): 84-101

7. Dominicus H (2014) Future of city tourism conference: welcome \& session one - importance of tourism to cities. [Online] Available at: https://www.youtube.com/watch?v=tYLeI_SU2Zo. Accessed 17 Aug 15

8. Dunne G, Flanagan S, Buckley J (2010) Towards an understanding of international city break travel. Int J Tour Res 12:409-417

9. Egger R (2013) The impact of near field communication on tourism. J Hosp Tour Technol 4(2):119-133

10. Ericsson (2015) Ericsson Mobility Report - On the Pulse of the Networked Society, June 2015. [pdf] Stockholm: Ericsson. Available at: http://www.ericsson.com/res/docs/2015/ericssonmobility-report-june-2015.pdf. Accessed: 16 July 2015

11. Eriksson N (2015) Travellers' intended future trip arrangement strategies for things to do during a trip: implications for travel distribution. In: Tussyadiah I, Inversini A (eds) Information and Communication Technologies in Tourism 2015: Proceedings of the International Conference in Lugano, Switzerland, February 36, 2015. Springer International Publishing

12. Euromonitor International (2015) Top 100 City Destinations Ranking [Online] Available at: http://blog.euromonitor.com/2015/ 01/top-100-city-destinations-ranking.html. Accessed 04 Aug 15

13. Füller H, Michel B (2014) 'Stop being a tourist!' New dynamics of urban tourism in Berlin-Kreuzberg. Int J Urban Regional 38(4): 1304-1318

14. Gibson C (2009) Geographies of tourism: critical research on capitalism and local livelihoods. Prog Hum Geogr 33(4):527-534

15. Guttentag D (2013) Airbnb: disruptive innovation and the rise of an informal tourism accommodation sector. Current Issues in Tourism, $1-26$

16. Hempel J (2012) With neighborhoods, Airbnb expands its horizons. Fortune. [Online] 13 November. Available at: http://fortune.com/ 2012/11/13/with-neighborhoods-airbnb-expands-its-horizons/. Accessed 20 Aug 15

17. IPK International (2013) ITB World Travel Trends Report, December 2013. Prepared by IPK International on behalf of ITB Berlin [pdf] Munich. IPK International. Available at: http://www. itb-berlin.de/media/itb/itb dl all/itb presse all/WTTR Report 2014_Web.pdf. Accessed: 4 Aug 2015

18. IPK International (2015) Tourismus als globaler Wachstumstreiber. Press Release at ITB Berlin, 4. März 2015

19. McCabe S, Sharples M, Foster C (2012) Stakeholder engagement in the design of scenarios of technology-enhanced tourism services. Tour Manage Perspect 4:36-44 
20. Minazzi R, Mauri AG (2015) Mobile technologies effects on travel behaviours and experiences: a preliminary analysis. In: Tussyadiah I, Inversini A (eds) Information and Communication Technologies in Tourism 2015: Proceedings of the International Conference in Lugano, Switzerland, February 3-6, 2015. Springer International Publishing

21. Neuhofer B, Buhalis D (2013) Technology Enhanced Tourist Experiences: a holistic exploration of how technology can enhance tourist experiences [Online] Available at: http://blogs. bournemouth.ac.uk/etourismlab/?s=enhanced. Accessed 21 July 15

22. Neuhofer B, Buhalis D, Ladkin A (2015) Technology as a catalyst of change: enablers and barriers of the tourist experience and their consequences. In: Tussyadiah I, Inversini A (eds) Information and Communication Technologies in Tourism 2015: proceedings of the International Conference in Lugano, Switzerland, February 3-6, 2015. Springer International Publishing

23. Ohta M, Watanabe Y, Miyazaki T (2015) Spatiotemporal analysis of rambling activities: approach to inferring visitor satisfaction. In: Tussyadiah I, Inversini A (eds) Information and Communication Technologies in Tourism 2015: proceedings of the International Conference in Lugano, Switzerland, February 3-6, 2015. Springer International Publishing

24. Pulvirent S (2015) Google maps is adding search and directions for offline use. [Online] Available at: http://skift.com/2015/05/29/ google-maps-is-adding-search-and-directions-for-offline-use/. Accessed 21 Aug 15

25. Rosa H (1999) Rasender Stillstand? Individuum und Gesellschaft im Zeitalter der Beschleunigung. In: Manemann J (ed.) Jahrbuch Politische Theologie, Bd. 3: Befristete Zeit, Münster, pp. 151-176

26. Rosa H (2003) Social acceleration: ethical and political consequences of a desynchronized high-speed society. Constellations 10(1):3-33

27. Rosa H (2015) Social acceleration: a new theory of modernity. Columbia University Press, Chichester

28. Rossini A (2014) The rise of mobile to drive bookings of indestination services. [Online] Available at: http://www.tnooz.com/ article/mobile-bookings-in-destination-services/. Accessed 27 July 15

29. Skift and Peak (2014) The rise of experiential travel, Skift report 2014 [pdf] Available at: http://skift.com/wp-content/uploads/2014/ 06/skift-peak-experiential-traveler-report1.pdf. Accessed: 3 July 2015

30. Stamboulis Y, Skayannis P (2003) Innovation strategies and technology for experience-based tourism. Tour Manage 24:35-43
31. Thomas O (2012) Airbnb is turning itself into a local-business guide, Business Insider. [Online] 13 December. Available at: http://www.businessinsider.com/airbnb-local-business-localmindnabewise-acquisition-2012-12?IR=T. Accessed 20 Aug 15

32. TourMIS (2014) Overnight stays in European Cities [Online] Available through the Austrian National Tourist Office. Available at: http://www.tourmis.info/index e.html. Accessed 12 Aug 2014

33. Tripadvisor (2013) TripBarometer Mobile \& Social Survey Finds $85 \%$ of US Travelers Bring Their Smartphones on Vacation \& 61 $\%$ Report Using Social Media While Traveling. [Online] Available at: http://www.tripadvisor.com/TripAdvisorInsights/n2006/ tripbarometer-mobile-social-survey-finds-85-us-travelers-bringtheir-smartphones-vacation-61-report. Accessed 23 Aug 15

34. Tripadvisor (2015) TripBarometer 2015: Five key traveler trends. [Online] Available at: http://www.tripadvisor.com/ TripAdvisorInsights/n2582/tripbarometer-2015-five-key-travelertrends. Accessed 23 Aug 15

35. Tussyadiah I, Inversini A (eds.) Information and communication technologies in tourism 2015: proceedings of the international conference in Lugano, Switzerland, February 3-6, 2015. DEU: Springer International Publishing, Cham

36. UNWTO (2012) Global Report on City Tourism. AM Reports, Volume Six [pdf] Madrid: UNWTO. Available at: http:// dtxtq4w60xqpw.cloudfront.net/sites/all/files/pdf/am6 city platma. pdf. Accessed: 3 Aug 2015

37. UNWTO (2014) Global benchmarking for city tourism measurement. AM Reports, Volume Ten [pdf] Madrid: UNWTO. Available at: http://www.e-unwto.org/doi/pdf/10.18111/9789284416691. Accessed: 3 Aug 2015

38. UNWTO (2015) UNWTO Tourism Highlights 2015 Edition. [pdf] Madrid: UNWTO. Available at: http://www.e-unwto.org/doi/pdf/ 10.18111/9789284416899. Accessed: 5 Aug 2015

39. WELCOME GOODBYE (2014) Directed by Nana A.T. Rebhan [Film]. Germany

40. Xiang Z, Wang D, O'Leary JT, Fesenmaier DR (2014) Adapting to the Internet: trends in travelers' use of the web for trip planning. J Travel Res, 1-17. doi:10.1177/0047287514522883

41. Ye Q, Law R, Gu B, Chen W (2011) The influence of usergenerated content on traveler behavior: an empirical investigation on the effects of e-word-of-mouth to hotel online bookings. Comput Hum Behav 27:634-639

42. Zimmerman C, Hansen K, Vatrapu R (2014) A theoretical model for digital reverberations of city spaces and public places. Int $\mathrm{J}$ Electron Gov Res 10(1):46-62 